CRYSTAL STRUCTURE AND HIRSHFELD SURFACE ANALYSIS

OF A ONE-DIMENSIONAL COORDINATION

ORGANIC/INORGANIC HYBRID [(MOO3)(biim) $]_{\mathrm{n}}$

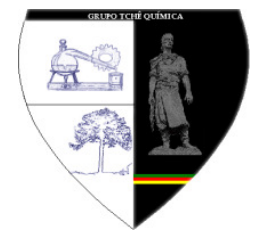

\title{
ANÁLISE DE ESTRUTURA CRISTALINA E SUPERFÍCIE HIRSHFELD DE UMA COORDENAÇÃO UNI-DIMENSIONAL HÍBRIDA ORGÂNICA/INORGANICA $[(\mathrm{MoO})(\mathrm{biim})]_{\mathrm{n}}$
}

\author{
MORALES Zaillmar ${ }^{1}$; ATENCIO Reinaldo ${ }^{2}$; RAMOS Miguel Angel ${ }^{2+}$; \\ BRUNO-COLMENÁREZ, Julia ${ }^{2^{*}}$
}

${ }^{1}$ Universidad del Zulia (LUZ), Facultad Experimental de Ciencias, Departamento de Química. Postal code 4005, Maracaibo, Estado Zulia-Venezuela. (phone: +58-0261-4124125)

${ }^{2}$ Instituto Venezolano de Investigaciones Científicas (IVIC), Centro de Investigación y Estructura de Materiales (CITEMA), Laboratorio de Materiales para Tecnologías Emergentes (LaMTE). Postal code 4005, Maracaibo,

Estado Zulia-Venezuela. (phone: +58-0212-5041353)

${ }^{2 \dagger}$ In Memoriam of our beloved friend and colleague Miguel Angel Ramos.

${ }^{*}$ Corresponding author

e-mail: julia.brunoc@gmail.com

01 December 2017; received in revised form 15 March 2018; accepted 06 April 2018

\section{RESUMO}

Um novo híbrido orgânico/inorgânico unidimensional $\left[\left(\mathrm{MoO}_{3}\right)(\text { biim })\right]_{n}$ foi sintetizado por método hidrotérmico em um reator Parr. Sua estrutura foi caracterizada por estudos espectroscópicos FT-IR e difracção de raios-X de um único cristal. Este composto cristaliza no sistema ortorrombico com o grupo espacial Cmc21,

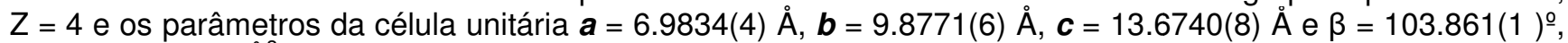
$V=1026,64(18) \AA^{3}$. A estrutura molecular e a embalagem de cristal são estabilizadas principalmente por fortes ligações de hidrogênio intermoleculares com átomos $\mathrm{N}-\mathrm{H}$... O que podem ser descritos pelo símbolo de conjunto de grafos $R^{2}{ }_{2}(9)$ e sua disposição de embalagem reforçada por empilhamento de $\pi-\pi$. Os intercontatos na estrutura do cristal são analisados usando o método computacional de superfícies de Hirshfeld.

Palavras-chae: Síntese hidrotermal; Híbrido inorgânico/orgânico; Análise da estrutura de cristal; Análise de superfície de Hirshfeld.

\begin{abstract}
A new one-dimensional organic/inorganic hybrid $\left[\left(\mathrm{MoO}_{3}\right)(\right.$ biim $\left.)\right] n$ has been synthesized by a hydrothermal method in a reactor Parr. Its structure was characterized by FT-IR spectroscopic studies and single-crystal $\mathrm{X}$-ray diffraction. This compound crystallize in the orthorhombic system with space group $\mathrm{Cmc2}_{1}$, $Z=4$, and unit cell parameters $\boldsymbol{a}=6.9834(4) \AA, \quad \boldsymbol{b}=9.8771(6) \AA, \boldsymbol{c}=13.6740(8) \AA$, and $\beta=103.861(1)^{\circ}$, $\mathrm{V}=1026.64(18) \AA^{3}$. The molecular structure and crystal packing are stabilized mainly by a strong intermolecular hydrogen bonds with atoms $\mathrm{N}-\mathrm{H} \cdots \mathrm{O}$ which can be described by graph set symbol $\mathrm{R}^{2}{ }_{2}(9)$ and its packing arrangement reinforced by $\pi-\pi$ stacking. The intercontacts in the crystal structure are analyzed using Hirshfeld surfaces computational method.
\end{abstract}

Keywords: Hydrothermal synthesis; Inorganic/organic hybrid; Crystal Structure analysis; Hirshfeld surface analysis. 
INTRODUCTION:

Within the most interesting nanostructured porous solid materials are organic metal structures (MOFs) which are composed of center metallic and, organic ligands. These last can act either as spacer or bridges inside the crystal structure, and its proper choice allows the design of new architectures with properties made to order like as applications in the area of catalysis, magnetism and particularly in gas storage (Pope, 1991; Cheetham, 1994).

For this reason, countless efforts have been invested in designing optimal strategies for the synthesis of this kind of materials. One of the strategies used in the synthesis of organic metal structures (MOFs) is to assemble together with organic species under hydrothermal conditions, in order to reduce the use of solvents and decrease the reaction time (Zhang et. al., 1997; Tong, 2000; Lu, 2002, Zapf, 1997). However, still under these conditions, it has been demonstrated that functionalization or modification of the metal topology is determined by the stereochemical characteristics of the organic component (Hagrman et. al., 1999).

Therefore, knowing that the hydrothermal synthesis offers a powerful synthetic route for the design of novel materials (Stupp, 1997; Hagrman et. al., 1999) we will explore the capabilities of 2,2-biimidazole as a potential building block for the synthesis of organic metal structures under these synthesis conditions. Here, we report the application of this technique to the cooperative assembly of molybdenum oxide / organic phases that have resulted in the formation of $\left[\left(\mathrm{MoO}_{3}\right)(\right.$ biim) $] \mathrm{n}(\mathbf{1})$ a new one-dimensional chain which was synthesized by hydrothermal methods structurally characterized by spectroscopic method (FT-IR), X-ray diffraction and analysis of intercontacts by Hirshfeld surfaces.

\section{PARTE EXPERIMENTAL}

All reagents for the synthesis were purchased as reagent grade and used without further purification. The FT-IR spectrum for the title compound was recorded on a Perkin Elmer Spectrum GX spectrometer employing a $\mathrm{KBr}$ disc, in the region from 400 to $4000 \mathrm{~cm}^{-1}$. FT-IR $(\mathrm{KBr}), \quad 0 \quad \mathrm{~cm}^{-1}: 3481,51 \quad[\mathrm{~N}-\mathrm{H}], 1670 \quad[\mathrm{C}=\mathrm{C}]$, $1436,97[\mathrm{C}=\mathrm{N}], 1217[\mathrm{C}-\mathrm{H}], 887,26 \quad[\mathrm{Mo}=\mathrm{O}]$, 744,52 [Mo-O].
Elemental analysis $(\mathrm{C}, \mathrm{H}, \mathrm{N})$ were determined with TruSpec CHN Leco instrument and the analyses indicate the following stoichiometry $\mathrm{C}_{6} \mathrm{H}_{6} \mathrm{MoN}_{4} \mathrm{O}_{3}$ : Calculated: $\mathrm{C}, 25.92$; $\mathrm{H}, 2.16$; N, 20.16\%. Experimental: $\mathrm{C}, 25.71 ; \mathrm{H}$, $2.44 ; \mathrm{N}, 19.78 \%$

\section{Synthesis of complex 1 .}

A mixture of Molibdeno oxide $\left[\mathrm{MoO}_{3}\right](3$ $\mathrm{mmol}$ ) and 2,2 biimidazole $(3 \mathrm{mmol})$ in water (8 $\mathrm{ml}$ ) was placed in a Teflon vessel which was inserted into a stainless steel reactor and sealed, then heated to a temperature of $180{ }^{\circ} \mathrm{C}$ for 48 hours. The reaction mixture was cooled and filtered, washed with cold water and finally dried. The best suitable crystals were chosen for the single crystal X-ray diffraction characterization. Blue rectangular crystal $(0.18,0.11$ and 0.022 $\mathrm{mm}$ ) was used for data collection.

\section{X-ray single-crystal crystallography}

The single crystal X-ray diffraction analysis was carried out on a KAPPA APEX II DUO Diffractometer with a graphite monochromator and Mo-Ka radiation $(\lambda=0.71069$ $\AA$ A) operating at $50 \mathrm{kV}$ and $30 \mathrm{~mA}$. A total of 3528 frames were collected with $\phi$ and $\omega$ scans' every $0.30^{\circ}$ for $10 \mathrm{~s}$ each (Bruker 2004). The structure was solved and refined using the SHELX Software Package (Sheldrick, 2015). In the resolution of the crystal structure the nonhydrogen atoms were refined anisotropically, while the hydrogen atoms bound to $\mathrm{C}$-atoms were placed geometrically and refined using a riding model, with $\mathrm{C}-\mathrm{H}=0.93 \AA$, Uiso $(\mathrm{H})=1.2$ Ueq $(\mathrm{C})$ for aryl $\mathrm{H} ; \mathrm{N}-\mathrm{H}=0.86 \AA$ and Uiso $(\mathrm{H})=$ $1.2 \operatorname{Ueq}(\mathrm{N})$ and $\mathrm{O}-\mathrm{H}=0.82 \AA$ and Uiso $(\mathrm{H})=$ $1.2 \mathrm{Ueq}(\mathrm{O})$. The final refinement values converge to $\mathrm{R} 1=0.0896, \mathrm{wR} 2=0.2455$ and $\mathrm{S}=1.172$ respectively. Table 1 contains the crystal data and refinement, as well as, bond distances and angles for this compound in Table 2. All the figures (ORTEP, packing and hydrogen bonding) were plotted using Diamond program (Brandenburg, 2001). All geometrical calculations were done using the Platon program (Spek, 2003). X-ray crystallographic data for this structure has been deposited at the Cambridge Crystallographic Data Center under code CCDC 1527112. Copies of the data can be obtained free of charge on application to The Director, CCDC, 12 Union Road, Cambridge CB2 1EZ, UK (fax: p44-1223-336033; e-mail: deposit@ccdc.cam.ac.uk). 
Hirshfeld surface analyses were carried out and fingerprint plots were plotted using CRYSTAL EXPLORER program (Wolff et. al., 2007).

\section{RESULTS AND DISCUSSION:}

Compound (1) crystallizes in space group $\mathrm{Cmc2}_{1}$ with cell parameters $\boldsymbol{a}=18.1535(18), \boldsymbol{b}=$ 3.8379(4), $\boldsymbol{c}=14.7354(15) \AA, V=1026.64(18)$ $\AA^{3}, Z=4, d c=1.489 \mathrm{~g} \mathrm{~cm}^{-3}$. The molecular structure and its atom-labeling scheme are presented in figure 1. A search previous in the Cambridge Structural Database (CSD, version 5.37, Feb. 2016) (Allen, 2002) no produced any results of similar structures.

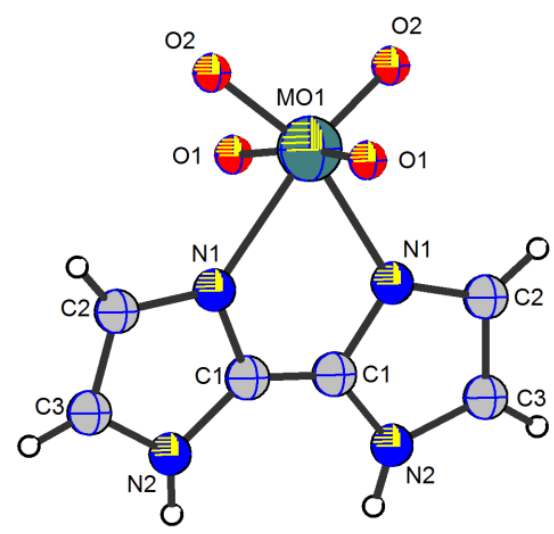

Figure 1. View of compound (1) with its atomlabeling scheme.

In the structure molecular of Compound (1), the $\mathrm{Mo}(1)$ atom center lies on a $(0,0,0)$ inversion center and is coordinated by the two nitrogen atoms from bidentate ligand 2,2'biimidazole and four oxygen atoms, two of them located in the equatorial plane (forming a polymer of coordination) and the other two in axial position, adopting a distorted octahedral geometry with a volume of $9.420 \AA^{3}$. Two identical Mo-N distances are observed at $2.234 \AA$ and the Mo-O distances are in the range between 1.66 (3) and 1.67 (2) $\AA$. The rings from the structure of 2,2'-biimidazole show planar conformation, however, in the complex it is observed the formation of a 5-membered ring formed by the bond of the molybdenum atom with the 2,2'-biimidazole structure; this 5-membered ring exhibits a conformation envelope on $\mathrm{Mo}(1)$.

As shown in Table 3, compound (1) present one strong conventional hydrogen bond between the $\mathrm{N}-\mathrm{H}$ group from 2,2'-biimidazole molecule and the oxygen atoms of the neighbor coordination complex, thereby this hydrogen bond pattern N2-H2a $\cdots \mathrm{O} 2[\mathrm{x}, 1-\mathrm{y},-1 / 2+\mathrm{z}]$ bond each the polymer chains that grown along $c$-axis (Figure 2). These hydrogen bond patterns can be described by graph set symbol $R_{2}^{2}(9)$.

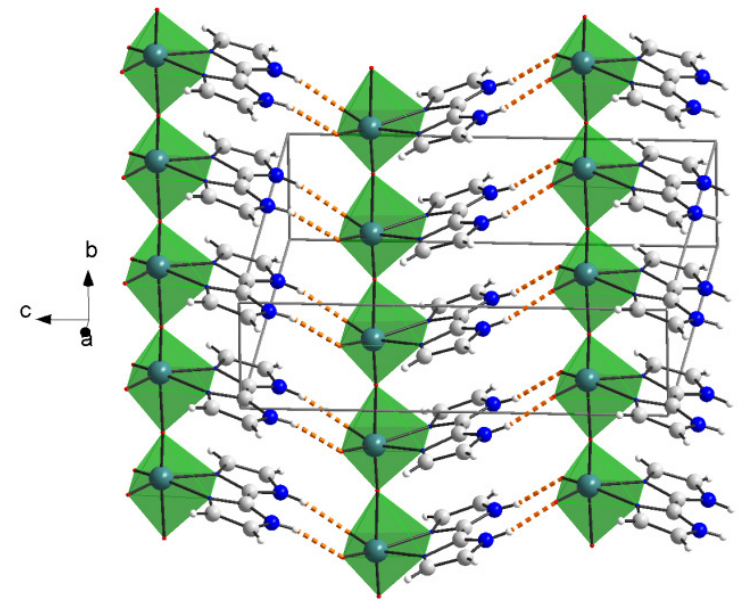

Figure 2. View of hydrogen bond pattern with graph $R_{2}^{2}(9)$ in the packing arrangement of compound (1). For interpretation of the references to color in this figure legend, the reader is referred to the web version of this article.)

On the other hand, these polymer chains are bonded between them by $\pi$-stacking interactions between each one of 2,2'-biimidazole molecule which presents a distance of the ringcentroids of $3.838(8) \AA$. These $\pi$-stacking interactions are hence crucial for the crystal packing stabilization and are largely responsible for the thermodynamic stability of the crystal system because keeping the 2,2'-biimidazole molecules in the polymer chain in cis-position.

The crystallographic unit does not show any coordinated solvent molecules, however, the packing arrangement of title compound present a potential solvent area with a volume of $184.9 \AA^{3}$ corresponding to $18.0 \%$ of total unit cell volume.

All these intermolecular interactions are quantified using Hirshfeld surface analysis (Spackman et. al., 2002, 2008, 2009; McKinnon, 2007; Hirshfeld, 1977). The close-contact interactions, like hydrogen bond contacts, are represented in figure 3, by the large and deep red spots on the 3D Hirshfeld surfaces (Parkin, et. al., 2007; Rohl et. al., 2008). The small red spots on the surfaces of 2,2-biimidazole molecule represent the $\mathrm{C}-\mathrm{H} \ldots \pi$ interactions. The 2-D fingerprint plots are shown in figure 5 . With the help of these analysis results, different interactions can be separated from each other that would commonly overlap in full fingerprint 
plots.
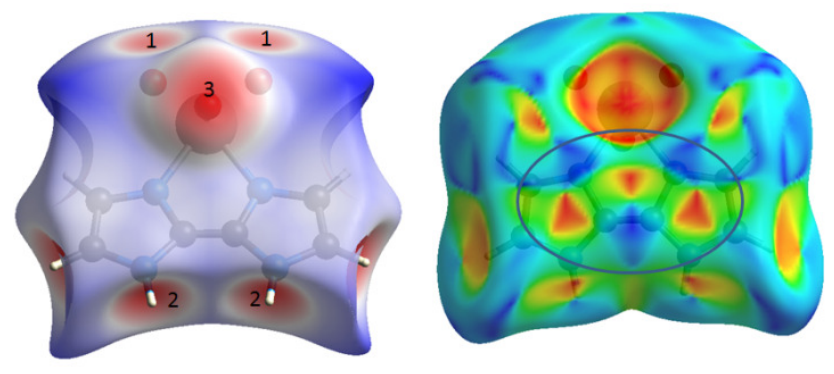

Figure 3. (a) Left: dnorm mapped on Hirshfeld surface for visualizing the intercontacts of the title compound. (b) Right: Shape index for the title compound (1).

Figure 4 indicates the contribution of intercontacts to the Hirshfeld surfaces, $\mathrm{H}-\mathrm{H}(35,5 \%)$, $\mathrm{O}-\mathrm{H}(30,8 \%), \quad \mathrm{C}-\mathrm{H}(6,5 \%), \quad \mathrm{C}-\mathrm{N}(4,9 \%), \quad \mathrm{C}-\mathrm{C}$ $(4,9 \%)$, O-O (4,7\%), Mo-O (4,5\%), N-O (4,2\%), $\mathrm{N}-\mathrm{N}(2,2 \%), \mathrm{N}-\mathrm{H}(1,6 \%)$, and $\mathrm{C}-\mathrm{O}(0.2 \%)$. In compound (1) the $\mathrm{H}-\mathrm{H}$ interactions, which are reflected in the middle of scattered points in the 2-D fingerprint plots, exhibit the most significant contribution $(35,5 \%)$ to the total Hirshfeld surfaces. It is possible to observe two highly directional contributions demonstrated by the elongated and fine peaks observed in the fingerprint, corresponding to Mo-O interactions $(4.5 \%)$ which are responsible for the formation of the chain polymeric; as well as the $\mathrm{O}-\mathrm{H}$ interactions $(30.8 \%)$, which are responsible for the formation of hydrogen bonds $\mathrm{N}-\mathrm{H}$... O with graph-set symbol $R_{2}^{2}(9)$ linking each polymer chain. These last ones are highlighted by conventional mapping of dnorm on molecular Hirshfeld surfaces are shown in Figure 3a (labels 1-2). The red spots on the surface indicate the intercontacts involved in the hydrogen bonds $\mathrm{N}$ $\mathrm{H}$...O described above.

In order to evaluate the presence of $\pi$ stacking interactions, a close examination with Shape index generally used to identify planar stacking arrangements was performed. These interactions are identified by the adjacent red and blue triangles on the shape index surfaces, as can be seen in figure $3 b$ when is possible to observe the pattern of red and blue triangles on the same region of the shape index surface, demonstrating that the molecules overlap and make contact with each other. Blue triangles represent convex regions due to ring carbon atoms of the molecule inside the surface, while red triangles represent concave regions due to carbon atoms of the $\pi-\pi$ stacked molecule above it. Figure 4, that contains the percentages of contributions of intermolecular contacts, it can be seen that the C-C contacts, associated with $\pi$ stacking interactions which are minimal in the compound under study, representing only $4.9 \%$ of the total Hirshfeld surface area.

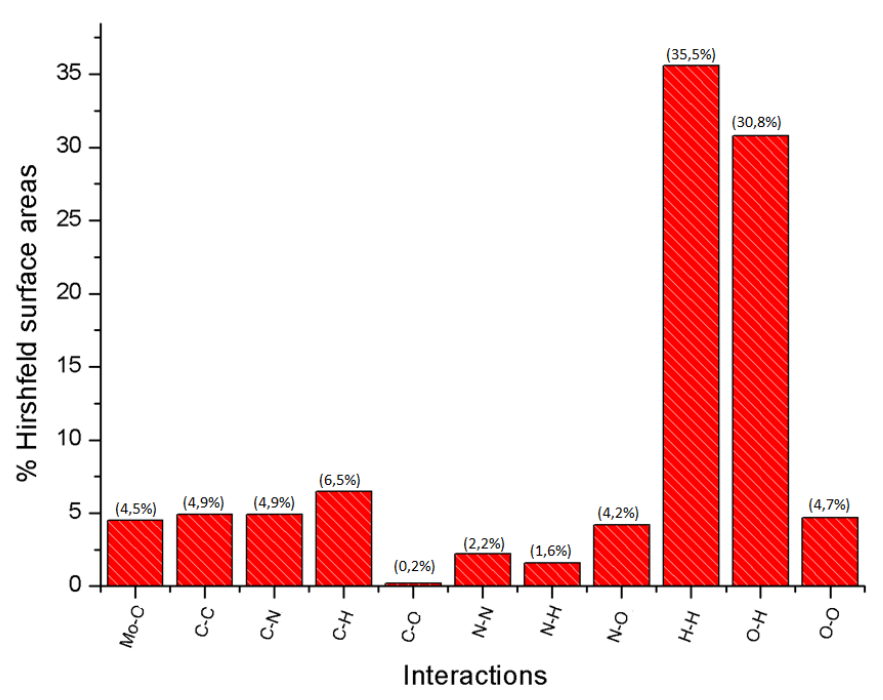

Figure 4. Percentage of various intermolecular contacts contributed to the Hirshfeld surface

\section{CONCLUSIONS:}

In conclusion, it demonstrates that the formation of the hydrogen bond pattern $\mathrm{N}-\mathrm{H} \cdots \mathrm{O}$, with graph-set symbol $\mathrm{R}_{2}^{2}(9)$, are the majority responsible for the supramolecular assembly of compound (1) in comparison to the m-stacking interactions. These quantitatively authenticated observations display the effectiveness of Hirshfeld surface to gain insights into the intermolecular interactions in the context of crystal engineering as well as, it is evidenced that the hydrothermal synthesis is a method effective for the preparation of a new compound and a new branch for the application of polyoxometalates.

\section{REFERENCES:}

1. Pope, M and Muller, A. Polyoxometalate Chemistry: An Old Field with New Dimensions in Several Disciplines, Angew. Chem., Int. Ed. 1991, 30, 34-48.

2. Cheetham, A. Advanced Inorganic Materials: An Open Horizon, Science, 1994, 264, 794-795. 
3. Zhang, Y; Zapf, P; Meyer, L; Haushalter R and Zubieta, J. Polyoxoanion Coordination Chemistry: Synthesis and Characterization of the Heterometallic, Hexanuclear Clusters [\{Zn(bipy) $\left.\left.{ }_{2}\right\}_{2} \mathrm{~V}_{4} \mathrm{O}_{12}\right]$, $\left.\left[\{\mathrm{Zn} \text { (phen) })_{2}\right\}_{2} \mathrm{~V}_{4} \mathrm{O}_{12}\right] \cdot \mathrm{H}_{2} \mathrm{O}, \quad$ and $\left[\left\{\mathrm{Ni}(\text { bipy })_{2}\right\}_{2} \mathrm{Mo}_{4} \mathrm{O}_{14}\right]$, Inorg. Chem. 1997, 36, 2159-2165.

4. Zhang, $X$; Tong, $M$, and Chen, $X$. Hydrothermal synthesis and crystal structures of two bimetallic chain-like and cluster complexes $\left[\left\{\mathrm{Co}(\text { phen })_{2}\right\}_{2} \mathrm{~V}_{6} \mathrm{O}_{17}\right] \mathrm{n}$ and $\left.\left[\{\mathrm{Cu} \text { (phen })_{2}\right\}_{4} \mathrm{~V}_{10} \mathrm{O}_{29}\right] \cdot 6 \mathrm{H}_{2} \mathrm{O}$, Chem. Commun. 2000, 1817-1818.

5. Lu, Y; Wang, E.B; Yuan, M; Luan, G.Y; Li, Y.G; Zhang, H; Hu, C.W; Qin; Y.G and Chen, Y.B. Hydrothermal synthesis and crystal structure of a layered vanadium phosphate with a directly coordinated organonitrogen ligand: $\left[\mathrm{V}_{4} \mathrm{O}_{7}\left(\mathrm{HPO}_{4}\right)_{2}\left(2,2^{\prime}-\right.\right.$ bipy $)_{2}$ J J. Chem. Soc., Dalton Trans. 2002, 3029-3031.

6. Zapf, P.J; Hammond, R.P; Haushalter, R.C and Zubieta, J. Hydrothermal Synthesis and Structural Characterization of a Series of One-Dimensional Organic/Inorganic Hybrid Materials of the $\left[\left(\mathrm{MoO}_{3}\right) \mathrm{n}\left(2,2^{\prime}\right.\right.$-bipy $\left.) \mathrm{m}\right]$ Family: $\left[\mathrm{MoO}_{3}\left(2,2^{\prime}-\right.\right.$ bipy)], $\quad\left[\mathrm{Mo}_{2} \mathrm{O}_{6}\left(2,2^{\prime}\right.\right.$-bipy) $], \quad$ and $\left[\mathrm{Mo}_{3} \mathrm{O}_{9}\left(2,2^{\prime} \text {-bipy }\right)_{2}\right]$ Chem. Mater. 1997, 9, 2019-2024.

7. Hagrman, P.J; Hagrman, D and Zubieta, J. Organic-Inorganic Hybrid Materials: From "Simple" Coordination Polymers to Organodiamine-Templated Molybdenum Oxides, Angew. Chem., Int. Ed. 1999, 38, 2638-2684.

8. Stupp, S.I and Braun, P. Molecular Manipulation of Microstructures: Biomaterials, Ceramics, and Semiconductors, Science. 1997, 272, 1242-1248.

9. Hagrman, D; Hagrman, P.J. and Zubieta, J. Solid-State Coordination Chemistry: The Self-Assembly of Microporous Organic-Inorganic Hybrid Frameworks Constructed from Tetrapyridylporphyrin and Bimetallic Oxide Chains or Oxide Clusters, Angew. Chem., Int. Ed. 1999, 38, 3165-3168.

10. Bruker, "APEX2 and SAINT-Plus," Bruker AXS Inc., Madison, 2004.

11. Sheldrick, G. M. Acta Cryst. 2015, C71, 3.

12. Brandenburg, K. Diamond. Crystal Impact GbR Bonn Germany, Version 2.1e. 2001

13. Spek, A. L. J. Appl. Cryst. 2003, 36, 7-13.
14. Wolff, S; Grimwood, D; McKinnon, J.J; Jayati-laka, D and Spackamn, M. A. Crystal Explorer 3.0. University of Westren Australia, Perth, 2007.

15. Allen, F. The Cambridge Structural Database: a quarter of a million crystal structures and rising, Acta Cryst. 2002, B58, 380-388.

16. Spackman, M.A. and McKinnon, J.J. Fingerprinting intermolecular interactions in molecular crystals, Cryst. Eng. Comm. 2002, 4, 378-392.

17. McKinnon, J.J; Jayatilaka, D; Spackman, M.A. Towards quantitative analysis of intermolecular interactions with Hirshfeld surfaces, Chem. Commun. 2007, 38143816

18. Spackman, M.A; McKinnon, J.J; Jayatilaka, D. Electrostatic potentials mapped on Hirshfeld surfaces provide direct insight into intermolecular interactions in crystals, Cryst. Eng. Comm. 2008, 10, 377-388.

19. Spackman, M.A and Jayatilaka, D. Hirshfeld surface analysis, Cryst. Eng. Comm. 2009, 11, 19-32.

20. Hirshfeld, F.L. Bonded-atom fragments for describing molecular charge densities, Theor. Chim. Acta, 1977, 44, 129-138.

21. Parkin, A; Barr, G; Dong, W; Gilmore, C.J; Jayatilaka, D; Mckinnon, J.J; Spackman, M.A and Wilson, C.C. Comparing entire crystal structures: structural genetic fingerprinting, Cryst. Eng. Comm. 2007, 9, 648-652.

22. Rohl, A.L; Moret, M; Kaminsky, W; Claborn, K; Mckinnon, J.J and Kahr, B. Hirshfeld Surfaces Identify Inadequacies in Computations of Intermolecular Interactions in Crystals: Pentamorphic 1,8-Dihydroxyanthraquinone, Cryst. Growth Des. 2008, 8, 4517-4525. 
Table 1. Crystal Data and Details of the Structure Determination for compound (1).

\begin{tabular}{|c|c|c|c|}
\hline \multicolumn{2}{|c|}{ Crystal Data } & \multicolumn{2}{|c|}{ Data Collection } \\
\hline Formula & $\mathrm{C}_{6} \mathrm{H}_{6} \mathrm{Mo} \mathrm{N} \mathrm{N}_{4} \mathrm{O}_{3}$ & Temperature (K) & 296 \\
\hline Formula Weight & 278.028 & Radiation $[\AA]]$ MoKa & 0.71073 \\
\hline Crystal System & Orthorhombic & $\Theta$ range $(\stackrel{0}{)})$ & $1.4,26.4$ \\
\hline Space group & $\mathrm{Cmc2}_{1}$ (No. 36) & hkl range & $\begin{array}{l}-22: 21 ;-4: 3 ;-18: \\
18\end{array}$ \\
\hline$a, b, c[\AA]$ & $\begin{array}{l}18.1535(18) \\
3.8379(4) \\
14.7354(15)\end{array}$ & $\begin{array}{l}\text { Tot., Uniq. Data, } \\
\text { R(int) }\end{array}$ & $6222,1054,0.039$ \\
\hline $\mathrm{V}\left[\AA^{3}\right]$ & $1026.64(18)$ & $\begin{array}{l}\text { Observed Data [I > } \\
0.0 \text { sigma }(I)]\end{array}$ & 995 \\
\hline Z & 4 & \multicolumn{2}{|c|}{ Refinement } \\
\hline $\mathrm{D}\left(\right.$ calc) $\left[\mathrm{g} / \mathrm{cm}^{3}\right]$ & 1.489 & Nref, Npar & 1054,60 \\
\hline $\mathrm{Mu}(\mathrm{MoKa})[/ \mathrm{mm}]$ & 0.681 & $\mathrm{R}, \mathrm{wR} 2, \mathrm{~S}$ & $0.0834,0.2283,1.16$ \\
\hline$F(000)$ & 460 & Flack $x$ & $0.07(3)$ \\
\hline Crystal Size [mm] & $0,18 \times 0,11 \times 0,022$ & Hooft $y$ & $0,27(0,05)$ \\
\hline CCDC & 1527112 & Min /Max. $\Delta \rho\left[\mathrm{e} / \AA^{3}\right]$ & $-0.67,0.84$ \\
\hline
\end{tabular}

Table 2. Bond distances and angles $(\AA ⿻ \circ 口)$ ) for compound (1).

\begin{tabular}{l|l|l|l}
\hline Mo1-O1 & $1.66(3)$ & N2-C1 & $1.420(16)$ \\
\hline Mo1-O2 & $1.67(2)$ & N2-C3 & $1.421(16)$ \\
\hline Mo1-N1 & $2.234(11)$ & C1-C1_c & $1.278(13)$ \\
\hline Mo1-O1_b & $2.18(3)$ & C2-C3 & $1.42(2)$ \\
\hline Mo1-O2_c & $1.67(2)$ & N2-H2A & 0.8600 \\
\hline Mo1-N1_c & $2.234(11)$ & C2-H2 & 0.9300 \\
\hline N1-C1 & $1.421(16)$ & C3-H3 & 0.9300 \\
\hline N1-C2 & $1.421(17)$ & & \\
\hline O1-Mo1-O2 & $97.9(17)$ & & \\
\hline O1-Mo1-N1 & $95(2)$ & Mo1-N1-C1 & $115.8(8)$ \\
\hline O1-Mo1-O1_b & $175(3)$ & Mo1-N1-C2 & $135.3(9)$ \\
\hline O1-Mo1-O2_c & $97.9(17)$ & C1-N1-C2 & $108.0(10)$ \\
\hline O1-Mo1-N1_c & $95(2)$ & C1-N2-C3 & $108.0(11)$ \\
\hline O2-Mo1-N1 & $91.3(8)$ & N1-C1-N2 & $108.0(9)$ \\
\hline O1_b-Mo1-O2 & $85.0(14)$ & N1-C1-C1_c & $117.8(11)$ \\
\hline O2-Mo1-O2_c & $103.2(11)$ & N2-C1-C1_c & $134.2(12)$ \\
\hline O2-Mo1-N1_c & $159.3(8)$ & N1-C2-C3 & $108.0(10)$ \\
\hline O1_b-Mo1-N1 & $81.6(16)$ & C1-N2-H2A & 126.00 \\
\hline O2_d-Mo1-N1 & $159.3(8)$ & C3-N2-H2A & 126.00 \\
\hline N1-Mo1-N1_d & $71.3(4)$ & N2-C3-C2 & $108.1(10)$ \\
\hline O1_b-Mo1-O2_c & $85.0(14)$ & N1-C2-H2 & 126.00 \\
\hline O1_b-Mo1-N1_c & $81.6(16)$ & C3-C2-H2 & 126.00 \\
\hline O2_d-Mo1-N1_c & $91.3(8)$ & N2-C3-H3 & 126.00 \\
\hline Mo1-O1-Mo1_a & $175(4)$ & C2-C3-H3 & 126.00 \\
\hline Symmery transforman & & \\
\hline
\end{tabular}

Symmetry transformations used to generate equivalent atoms:

$a=x,-1+y, z \quad b=x, 1+y, z \quad c=1-x, y, z$ 
Table 3. Hydrogen bonds patterns for compound (1) $(\AA, \stackrel{\circ}{)})$

\begin{tabular}{lllllll}
$\mathrm{H}-$ Bond & $\mathrm{D}-\mathrm{H}$ & $\mathrm{H}-\mathrm{A}$ & $\mathrm{D}-\mathrm{A}$ & $\mathrm{D}-\mathrm{H}-\mathrm{A}$ & Symmetry & Motif \\
$\mathrm{N} 2-\mathrm{H} 2 \cdots \mathrm{O} 2$ & 0,8600 & 1.9100 & $2.75(2)$ & 165,00 & $\mathrm{x}, 1-\mathrm{y},-1 / 2+\mathrm{z}$ & $\mathrm{R}_{2}^{2}(9)$ \\
\hline
\end{tabular}

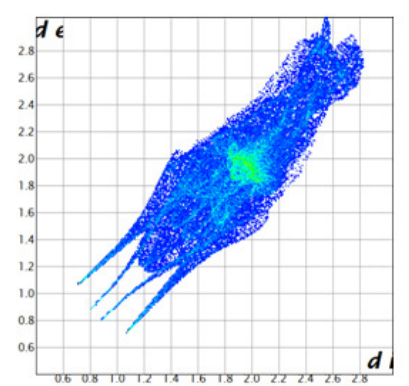

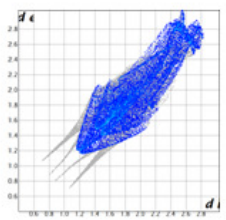

$\mathrm{H}-\mathrm{H}$

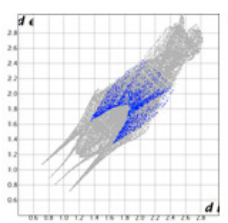

$\mathrm{N}-\mathrm{O}$

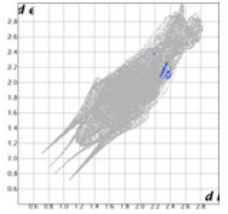

$\mathrm{C}-\mathrm{O}$

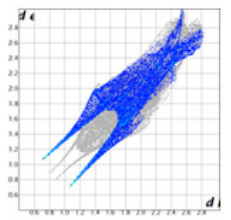

$\mathrm{H}-\mathrm{O}$

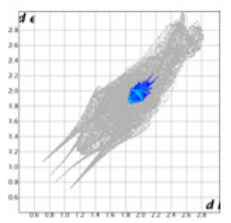

C-C

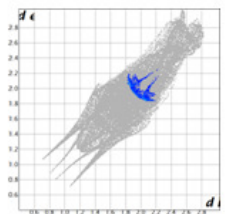

$\mathrm{N}-\mathrm{N}$

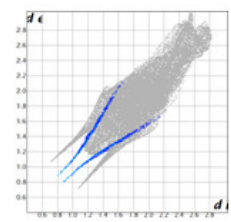

Mo-O

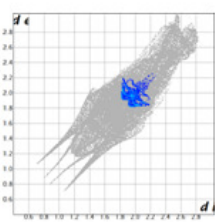

$\mathrm{N}-\mathrm{C}$

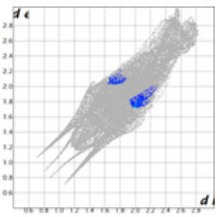

$\mathrm{N}-\mathrm{H}$

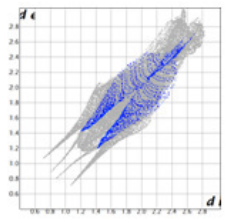

O-O

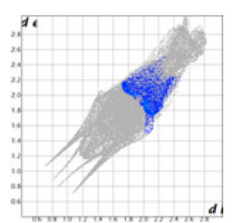

$\mathrm{C}-\mathrm{H}$

Figure 5. Detailed view of 2-D fingerprint plots with the main interactions showed inside the Hirshfeld surface for the title compound (1).

PERIÓDICO TCHÊ QUÍMICA • www.periodico.tchequimica.com • Vol. 15 N. 30.

- ISSN 1806-0374 (impresso) • ISSN 1806-9827 (CD-ROM) • ISSN 2179-0302 (meio eletrônico)

The Periódico Tchê Química (ISSN: 1806-0374; 2179-0302) is an open-access journal since 2004. Journal DOI: 10.52571/PTQ. http://www.tchequimica.com. This text was introduced in this file in 2021 for compliance reasons.

(c) The Author(s)

OPEN ACCESS. This article is licensed under a Creative Commons Attribution 4.0 (CC BY 4.0) International License, which permits use, sharing, adaptation, distribution, and reproduction in any medium or format, as long as you give appropriate credit to the original author(s) and the source, provide a link to the Creative Commons license, and indicate if changes were made. The images or other third-party material in this article are included in the article 's Creative Commons license unless indicated otherwise in a credit line to the material . If material is not included in the article's Creative Commons license and your intended use is not permitted by statutory regulation or exceeds the permitted use, you will need to obtain permission directly from the copyright holder. To view a copy of this license, visit http://creativecommons.org/licenses/by/4.0/. 